\title{
Teaching Writing Narratives Online by Using Storyboard Technique During the Lockdown period of the Virus Covid-19 Outbreak
}

\author{
Edi Pujo Basuki ${ }^{1}$, Tiyas Saputri ${ }^{2}$ \\ ediayarga@unusa.ac.id \\ 1,2 FTTE,Nahdlatul Ulama University, Surabaya, Indonesia
}

Received: 17 November 2020 Accepted: 29 November 2020

DOI: $10.24256 /$ ideas.v8i2.1682

\begin{abstract}
Living among the virus covid-19 epidemic, lecturing was conducted online. One such learning technique is the storyboard technique. The media picture (storyboard) is a media that is a reproduction of the original form in dimensions, in the form of photographs or paintings. Storyboard technique is activity before writing that emphasizes the elaboration (detailed explanation) predictions or estimates, the growth of ideas, and sequencing. This study aims to (1) describe the process of pre- developing of a storyboard, (2) show a model of the sequence of the story of storyboard (3) show an inspiring lesson plan of teaching writing of narrative text online using storyboard technique. The design of this study is descriptive qualitative. The design of this study is descriptive qualitative. The research framework is semantic construction, specifically limits the focus on coherence. The construction of the pre-developing of the storyboard is built on two concepts: building the coherence theory of van Dijk's building text and the generic structure of the narrative text. The result of this study are (1) In order to produce a storyboard in creating narrative text, the teacher should simplify the global coherence of complex story to the local one, after that it is continued by the technique of visualization as following the generic structure of a narrative text (2) The storyboard is drawn digitally (3) The lesson plan of teaching using this technique
\end{abstract}

Keywords: online teaching; storyboard technique; writing narrative text 


\section{Introduction}

Living among the virus convid-19 epidemic, lecturing were conducted online. The teaching of writing about narrative is hampered because explicit explanations by lecturers cannot be carried out. The alternatives given by the government to online teaching have been welcomed by the rector's policy. Because of that, creative and inspirational teaching is needed, which uses electronic media and digital resources that can be easily accessed by students. In the world of modern education, many learning techniques are offered by experts for teachers to use in learning activities in class, learning techniques offered vary according to the purpose, form and type of learning to be conveyed. One such learning technique is the storyboard technique. According to Ahmad Rohani (2007: 21), the media picture (storyboard) is as a media which is a reproduction of the original form in dimensions, in the form of photographs or paintings. The same thing was stated by Arsyadr (2006: 91) that visual forms can be in the form of representational images such as drawings, paintings or photographs that show the appearance of an object so as to facilitate understanding of information that has been convinced. According to Wiesendanger (2001: 161), storyboard technique is an activity before writing that emphasizes the elaboration (detailed explanation) predictions or estimates, the growth of ideas, and sequencing. This is used to motivate students to develop their ability to write, which begins by examining a sketch in the form of a picture and then develop it into a paragraph. This storyboard technique involves reading, writing and illustrating. This is effective because it motivates novice writers.

The storyboards in this research are in the form of sequential stories with interesting and inspirational designs in digital form. Because depictions are made digitally paperless. Writing skills are one of language skills and are more difficult to master for language learners. Writing activity is one of the activities carried out to produce writing that is created from the form of thoughts or feelings of a person.

Writing skill is just as important as other language skills, and in fact writing languages are making rapid progress. Writing can be said as an activity to convey the intent and purpose of an idea. Writing is a basic skill that everyone has. Often a person cannot express it in writing. Therefore, writing becomes an important skill. Ideas that are already in the mind can be poured into a writing. Although it has been realized that writing skills are very necessary in modern times, but in reality teaching writing in schools is still not good.

Many factors cause the lack of student skills in writing, especially short story creative writing. Writing difficulties are often caused by complex problems in writing. A writer is not only required to master the problems to be written, but also must master the basic elements of writing. The main elements are discovery, arrangement, and style (Enre, 1988: 7). In applying the 2013 curriculum, one of the writing competencies in learning activities is writing short stories. English Teacher Program students who later become English teachers must be able to become figure to their students how to write better. Writing activities in the narrative genre 
is to tell a story or tell a life event according to the correct plots.

One problem that usually arises, is that students sometimes have difficulty developing ideas and lack of coherence techniques that give impact on the low ability of students to produce a work in the form of short stories. On the other hand, the short story text is one of the texts that requires a fairly high imaginative power in the process of compilation. To overcome these problems, learning techniques are needed that can help and facilitate students in writing paragraphs. Learning techniques are one of the elements that influence learning success. The use of learning techniques will attract student learning interest and make it easier for students to understand the material. One technique that can be used to help make it easier for students to write short story text is the storyboard technique. The storyboard technique will stimulate students' creative power to be creative in telling the story contained in the storyboard. This study aims to find out the process of pre- developing of a storyboard, to show a model of sequence of story of storyboard and to show an inspiring lesson plan of teaching writing of narrative text online using storyboard technique.

\section{Method}

Design of this study is descriptive qualitative. The research framework is semantic construction, specifically limits the focus on coherence. The construction of pre-developing of story board is built on two concepts: building the coherence theory of van Dijk's building text and the generic structure of narrative text. This study aims to (1) describe the process of pre- developing of a storyboard, to (2)show a model of sequence of story of storyboard and to (3) show an inspiring lesson plan of teaching writing of narrative text online using storyboard technique.

\section{Results}

\section{The construction of Pre- Developing of a Storyboard}

Teachers should know the cognitive process of the students that are aged as teenager, so that to make good storyboard, teachers do not just make sequence of picture without any consideration, and all done. The teacher should define first what students should imagine and then what they should shift to written form.

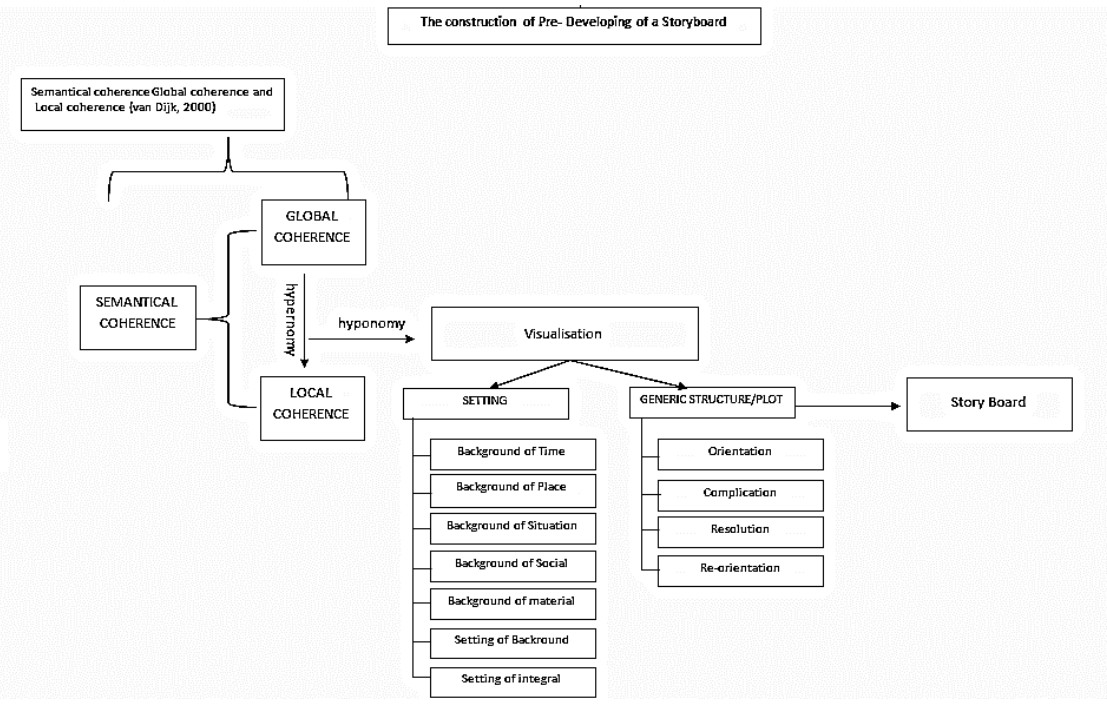


Figure 1. Construction of Pre-Developing Story Board

\section{Model of Sequence of Story Of Storyboard}

The writer can not to state all pictures here. So that to suit with the limited space of conference of proceeding paper, he stated one picture as example below. The pictures are made as interesting as it can. So that students will encourage to write their ideas

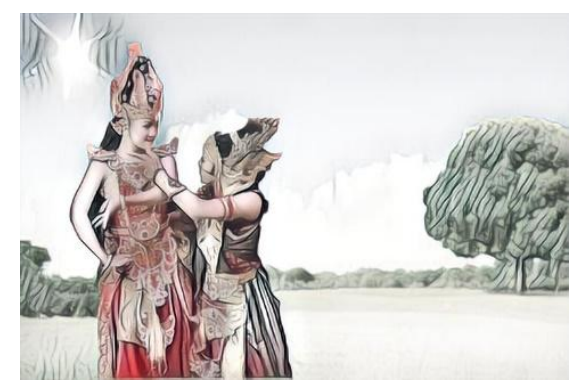

Figure 2. Model of Story Board

3. Lesson Plan of Teaching Writing of Narrative Text Online Using Storyboard Technique.

In order to teach writing online. The writer show the lesson plan as model of teaching by using this technique

(1) Make a good story board as follow the chart above and the pictures should be interesting and saved as png or jpg format so that can save and share digitally

(2) Open an online teaching process by using social media that can be accessedby all students in classroom

(3) Give clear command to students and make sure they understand well. Give brief command that they should write a story by following story board

(4) Show one pictire first and ask them what they see, make brainstorming. make sure that all elements of picture succeed to mention. This is for the students get the hyponomy.

(5) Give example to translate those elements of picture into sentences

(6) After that let them make their story freely.

(7) After 20 minutes. Ask three students to read their witing. 


\section{Discussion}

Ni'mah (2014) in her article which is entitled 'The writer used storyboard in teaching writing of narrative text for eight graders of SMPN 13 Surabaya'. She collected data through observation, writing task, and questionnaire. The result shows that the use of storyboard could help to stimulate the students' idea in writing narrative text also the students' responses toward the use of storyboard are positive.

It is proved that storyboard is helpful to stimulate the students' idea. Idea is the basic development in writing because the failure of writing is the writer stop to write.

To know the influence of using storyboard towards students' narrative text writing ability, we can read the article of Hasan (2016).In her article which is entitled 'Storyboard in Teaching Writing Narrative Text'. This research methodology used was quasi experimental design. In collecting the data, she used instrument of writing test. Based on the data analysis, it was found that the result of the data analysis computed by using SPSS was Sig 0.047 and $\alpha=0.05$. She found that there is a significant influence of using storyboard towards students' narrative text writing ability at the second semester in the tenth grade of SMAN 2 Bandar Lampung in the academic year of 2015/2016.

The two articles shown above can convince us that storyboard is meaningful to developing paragraphs of narrative text. From several articles I read, so far I know there limited research that analyze how to build storyboard based on construction the pictures themselves semantically. It means in my article I bring idea, that to construct the chronology of pictures, in order to stimulate students to build a good narrative text, the creator of pictures of storyboard should pay attention to coherence and cohesive of story. Because the students should define the teacher/creator' story idea which are formed in pictures into their writing paragraphs. The creator or teacher should shift the global coherence of sophisticated story into local coherence one. This means the teacher before make story board, he should define firstly the hypernomy into hyponomy. Because students will be easier to write their sentences if following the story board that simpler and suit with their mind. The good story board if it stimulate the students to write well.

After that, the teacher should make the pictures as interesting as well. He should pay attention to setting of background. If the story is about past era without technology, such as story of timun mas, ande ande lumut etc. The background setting should follow the era. Second, the sequence of story should follow generic structure of narrative. This is as quide to the students to make their own story to follow plotting of narrative text.

The other important is the technique of teaching should be arranged well. It made on base of the need, the age and the interest. The writer has shown one 
teaching procedure to help the reader get the points of his idea.

\section{Conclusion}

In order to make good story board, teachers should understand the cognitive process of the students that aged as teenager. They will produce a good writing if the pictures are understanable well and it can stimulate their mind to produce their own story without lose the coherence. The pictures that are to complicated will make the students fail to write. The pictures should be interesting and relevant with the story. They will not lose sense to write. In order to teach online throughout the COVID -19 pandemic there are procedures to teach writing online.

\section{References}

Adnan, B. (2013). Peningkatan Keterampilan Menulis Cerpen Melalui Teknik Papan Cerita (Storyboard) Siswa Kelas XI SMA Negeri 1 Minggir, Sleman. Skripsi S1. Prodi PBSI UNY.

Arsyad, A. (2006). Media Pembelajaran. Jakarta: Rajawali Pers.

Badger, R. and Goodith, W. (2000). A proces writing. ELT Journal Vol. 9 (2).

Brown, H. D. (1994_. Language Pedagogy. Cambridge: Cambridge University Press

Diponegoro, M. (1994). Yuk, Nulis Cerpen Yuk. Yogyakarta: Neosantri.

Essley, R. (2008). Visual Tools for Instruction: Strategies to Help Students Make Abstract Ideas Concrete \& Accessible. Washington: Scholastic Teaching Resources

Fithriani, T N. (2014). Keefektifan Strategi Wordless Picture Books Dalam Pembelajaran Menulis Cerpen Pada Siswa Kelas X SMA Negeri 1 Mlati, Sleman. Skripsi S1. Yogyakarta: Prodi PBSI UNY.

Furwana, D., \& Syam, A. (2019). Improving Students' Writing Skill on Descriptive Text By Estafet Strategy of the Eleventh Year Students of SMA 4 Palopo. IDEAS: Journal on English Language Teaching and Learning, Linguistics and Literature, 7(1). doi:https://doi.org/10.24256/ideas.v7i1.722

Hasan,K.Md \& Akhand, M.Mohd. (2010). Aprroaches to writing in EFL/ESL context: Balancing product and journal, 15(1-2):77

Halliday and Hasan . (1976). Coherence and Cohesion. London: Longman.

Hurford, Heasly, and Smith . (2007). Semantics. New York: Cambrige University Press

Knapp, W and Watkins, M. (2005). Teaching and assessing writing. Wales: Wales Press

Masruddin, M., \& Kurnia, K. (2018). Improving Students Writing Skill by Using Picture at the Twelfth Year Students of SMA Pesantren Modern Datok Sulaiman Putra Palopo. IDEAS: Journal on English Language Teaching and Learning, Linguistics and Literature, 3(2). doi:https://doi.org/10.24256/ideas.v3i2.152

Nurgiyantoro, B. (2010). Penilaian Pembelajaran Bahasa Berbasis Kompetensi. 
Edi Pujo Basuki, Tiyas Saputri

Teaching Writing Narratives Online by Using Storyboard Technique during the Lockdown period of the Virus Convid-19 Outbreak

Yogyakarta: BPFE.

Rohani, A. (2004). Pengelolaan Pengajaran. Jakarta: Rineka Cipta

Sayuti, S. A. (2000). Berkenalan dengan Prosa Fiksi. Yogyakarta: Gama Media.

Stamler, K. (2018) Learner Motivation and Persistence. New York: Cambrige University Press

Syafii, M. (2019). Improving the Quality in Writing Descriptive Texts of Madrasah Aliyah Students Through Directed Writing Activity Strategy. IDEAS: Journal on English Language Teaching and Learning, Linguistics and Literature, 7(2). doi:https://doi.org/10.24256/ideas.v7i2.1027

Tarigan, H. G. (2008). Menulis Sebagai Suatu Keterampilan berbahasa. Bandung: Angkasa.

Van D .(1977). Text and Context. London and New York: Longman.

Van D .(1980). The Semantics and Pragmatics of Functional Coherence in Discourse. Journal of Pragmatics 4: 233-252. 